\title{
TOURIST GUIDES' CONTRIBUTION TO SUSTAINABILITY IN ROMANIA
}

\author{
Corina-Florina TĂTAR* \\ University of Oradea, Department of Geography, Tourism and Territorial Planning, \\ 1 University st., 410087, Oradea, Romania, e-mail: corina_criste_78@yahoo.com \\ Grigore Vasile HERMAN \\ University of Oradea, Department of Geography, Tourism and Territorial Planning, \\ 1 University st., 410087, Oradea, Romania, e-mail: grigoreherman@yahoo.com

\section{Maria GOZNER} \\ University of Oradea, Department of Geography, Tourism and Territorial Planning, \\ 1 University st., 410087, Oradea, Romania, e-mail: mariagozner@yahoo.com
}

\begin{abstract}
Citation: Tătar, C., F., Herman, G., V., \& Gozner M., (2018). TOURIST GUIDES' CONTRIBUTION TO SUSTAINABILITY IN ROMANIA. GeoJournal of Tourism and Geosites, 21(1), 282-287. https://doi.org/10.30892/gtg.21122-287
\end{abstract}

\begin{abstract}
The study aims to identify the tourist guide's role and importance, as a mediator between demand and supply, between tourists and local collectivities in the support of local economy and sustainable tourism, within tourist destinations' areas. The current study was meant to highlight the degree to which tourist guides of Romania promote and abide by the sustainability issues in their guiding activity. This fact emerges alongside the development and expanding of tourist activities and subsequently human pressure on the natural milieu. A close-questions' questionnaire was applied to seventy national tourist guides, with a national geographical coverage of over $50 \%$, who participated at the annual national tourist guides' conference of Oradea city in the year 2017. The results showed that, in their guiding activity, guides promote host-guest interractions, encourage tourists to buy products from locals and care about vulnerable destinations.
\end{abstract}

Key words: tourist guide, sutainability, tourists' behaviour, local economy

\section{INTRODUCTION}

The current study comes as a sequel to previous studies concerning the tourist guides' ascending trend evolution and the critical aspects which they are confronted with in Romania (Tatar et al., 2017). At the level of Romania 4,335 licensed tour guides (Minsistry of Tourism of Romania, 2017) were recorded in the year 2016 which comes as a huge leap in this professional activity if compared to merely almost two decacdes ago, when only 28 licensed tour guides could be counted in the year 1998 .

\footnotetext{
* Corresponding author
} 
The legislation in force (i.e. Law Order number 637/2004) after the fall of the communist system in Romania allowed the proliferation of the number of tourist guides which currently envisages more such categories such as national, local and specialized. Within previous studies (Tatar et al., 2017) the analysis showed that in the year 2016 the largest share is held by national tour guides with $75 \%$, followed by the local guides with $20 \%$ and the specialized ones with $5 \%$. Being an activity in practice even since ancient times, in Ancient Greece tour guides were supposed to lead (periegetai) the group and explain (exegetai) the natural and man-made heritage (Comănescu, 2012) and later on during the Grand Tour, the acompanying guide had also the role of a mentor, basic skills that are maintained even today, to which more roles have been added such as that of a leader, educator, public relations representative, host and conduit (Pond, 1993). In the current globalisation, McDonalidisation (Shaw \& Williams, 2004) and acculturaltion trend of destinations local tourist guides should come to the forefront as representatives of local communities (Lovrentjev, 2015) and sustainably conduct tours that protect destinations and leave them unaltered for the future generations to enjoy too (Ungureanu, 2013; Gozner, 2012; Ilieș et al., 2008).

The term of tourist guide was preferred for use in this study in compliance with the World Federation of Tourist Guide Association (WFTGA) adopted terminology. The current paper is meant to enhance knowledge about the tourist guides' activity in Romania and highlight their interest into providing a sustainable output, thus more questions were addressed to the licensed tourist guides who attended the National Tourist Guides' Conference, which is organized in a different city of Romania annually. The survey was prepared for and applied to the licensed tourist guides of the National Tourist Guides' Conference of Oradea (i.e. Sustainable Tourism and the Tour Guide) held during 19-22nd of February 2017. There were seventy registered national tourist guides, with a wide national geographical coverage, who participated at the conference; out of them 58 filled in the questionnaire. The study was meant to highlight the degree to which tourist guides of Romania promote and abide by the sustainability issues in their guiding activity in the context in which the data collection year, 2017 for this study was declared the International Year for Sustainable Tourism, as postulated by the World Tourism Organisation and the World Federation of Tourist Guide Association. Sustainability in tour guiding refers to the tourist guides' ability to promote local economy by the stimulation to consume local products and services and create new responsible attitudes and behaviour in vulnerable destinations.

The guide is preoccupied to maintain the resources of the tourist destination and to encourage positive encounters between the host community and tourists ( $\mathrm{Hu} \&$ Wall, 2012). Sustainability is fostered through the natural and cultural heritage interpretation, by monitoring and role-modelling visitor behaviour in these areas (Weiler \& Kim, 2011), one of his/her stated role being that of a motivator of responsible behaviour (Randall \& Rollins, 2009). The tourist guides' focus is on knowledge transmission and skill acquisition, but according to Christie and Mason (2010) a good guiding activity should lead to a change in tourists' attitudes and behavior, a so-called transformative tour guiding so as to go beyond the mere presentation of a new environment, country or culture. Tourist guides undertake this activity either as a main or compelmentary job, some are either retired or semiretired from other professesions and often engaged in this activity for lifestyle rather than economic incentives (De Beer et al., 2013). A large share of tourist guides are freelancers whereas some are employed by tour operators. In many countries this occupation is low remunerated despite its high skilled required qualification (Collins, 2000). Within the current research it was showed that all respondents (i.e. licensed guides) had higher education studies. 


\section{METHODOLOGY}

This analysis relies on the data obtained at the national tourist guides' conference of Oradea, Romania during 19-22 ${ }^{\text {nd }}$ of February 2017. The conference entitled Sustainable Tourism and the Tourist Guide was organized in the context of the declaration of the year 2017 the year of sustainable tourism by the World Tourism Organization. A closed-questions questionnaire was distributed to the participants at the conference. The subjects included in the study were represented by the licensed tourist guides participating in the aforementioned conference. In order to pursue the established research objectives, the present study relies on the sociological survey method based on a questionnaire, a quantitative method of data collection and analysis (Chelcea, 2007; Bryman, 2012; Bar et al., 2016).

Regarding data collection, the questionnaire contained 5 items mainly referring to the role and importance of the tourist guide in developing and supporting the local economy in line with the principle of a sustainable and responsible development of the tourist destination areas in which each one operates. Also, socio-demographic data were included within the questionnaire, i.e. the age and level of graduate studies. The questionnaires were applied by face-to-face meetings which generated higher response rates (McGuirk \& O'Neill, 2005; Herman et al., 2016), so that out of 70 tour guides from across the entire country present at the conference, 58 filled out the questionnaire. According to the tour guides' origin, they came from the main cities of Romania and covered more than $50 \%$ of the national territory of Romania, according to the discussions held with the conference organizers.

\section{RESULTS AND DISCUSSIONS}

From the respondents' analysis by age group it was found that the largest share is held by the group of young people aged 20-34 years, $45 \%$ (26 persons), followed by the group of mature tourists, aged between 35-49 years, 33\% (19 persons) and older tourist guides, over 50 years old, $22 \%$ (13 persons).

The subjects' analysis which refers to the level of graduated studies reveals their uneven distribution, most (35 persons) being graduates of university studies, respectively post-graduate (23 persons). It should be noted that there aren't any guides only with high school education in the category of interviewed guides, which indicates the necessity of a high professional training in practicing the tourist guide job, which is then reflected indirectly in sustaining and developing the local economy in accordance with the principle of sustainable environmental development.

\section{The tourist guide's role in supporting the local economy}

In order to highlight the guide's role in supporting the local economy, respondents were consulted through two key issues. The first aspect was aimed at facilitating contact between tourists and locals, while the second aspect was centered on the idea of encouraging the stimulation of the local economy through tourism. Thus, from the analysis of the answers given in relation to the respondents' options in facilitating meetings between tourists and locals, most of them (54 persons) agree to it, while 2 persons disagreed. The remaining two people did not know how to respond (Table 1). Tourism has turned out to be a tool for economic development in the era of globalisation and industrialisation, on the backdrop of the demise of traditional industries such as logging, agriculture and livestock breeding (Wang et al., 2018), therefore many emerging global destinations rely on tourism as their main means of income. That is why the tourist guide has an important role to foster good relations among tourists and locals (Tatar, 2013) meant to enhance tourist experience satisfaction but to also educate tourists into consuming local products and buying locally-produced handicrafts and souvenirs. 
Table 1. The survey results referring to the role of the tourist guide in supporting the local economy

\begin{tabular}{|c|c|c|c|}
\hline Question & Yes & No & $\begin{array}{l}\text { Do not } \\
\text { know }\end{array}$ \\
\hline \multicolumn{4}{|c|}{ The role of the tourist guide in supporting the local economy } \\
\hline $\begin{array}{l}\text { 3. In the guided tour activity, do you choose to } \\
\text { facilitate meetings between tourists and locals? }\end{array}$ & 54 & 2 & 2 \\
\hline $\begin{array}{l}\text { 5. Do you encourage tourists to purchase products } \\
\text { from local producers in their destination? }\end{array}$ & 58 & $\mathrm{O}$ & $\mathrm{O}$ \\
\hline
\end{tabular}

The tourist guide's role in promoting the sustainable development of the tourist destination areas

In order to highlight the tourist guide's role in promoting the sustainable development of the tourist destination areas, a set of three questions regarding the accessibility of tourist resources for the next generations, the former capitalization and possible concerns addressed to the guided tourists were elaborated.

After analyzing the answers given by the respondents regarding their desire for the tourist resources to be accessible for the next generations it was found that all the interviewees ( 58 persons) agreed to it, there was no negative answer (Table 2).

The same idea of preserving, protecting and capitalizing on tourism resources also emerges from the analysis of respondents' answers to the question "If the tourist resource is vulnerable to the contact with tourists, do you suggest to them alternative attractions?" 47 people responded positively, while only 8 people responded negatively, the remaining 3 people did not know how to respond (Table 2).

A similar attitude towards the conservation, protection and capitalization of tourist resources has been observed to the interviewed tourists and the tourists with whom they have been involved over the years. Thus, at the question "Were the led tourists concerned about environmental protection?" fourty-four respondents answered positively, while there were only two negative responses. Twelve interviewed people on this subject did not know how to respond (Table 2).

Table 2. The survey results referring to the role of the tourist guide promoting the sustainable development of the tourist destination areas

\begin{tabular}{|c|c|c|c|}
\hline Question & Yes & No & Do not know \\
\hline \multicolumn{4}{|c|}{$\begin{array}{l}\text { The role of the tourist guide in promoting the sustainable } \\
\text { development of the tourist destination areas }\end{array}$} \\
\hline $\begin{array}{l}\text { 6. Do you want that the tourist resources } \\
\text { be accessible to future generations? }\end{array}$ & 58 & $\mathrm{O}$ & $\mathrm{O}$ \\
\hline $\begin{array}{l}\text { 4. If the tourist resource is vulnerable to } \\
\text { the contact with tourists, do you suggest to } \\
\text { them alternative attractions? }\end{array}$ & 47 & 8 & 3 \\
\hline $\begin{array}{l}\text { 7. Did you notice any tourists' concern for } \\
\text { the environment in your guiding activity? }\end{array}$ & 44 & 2 & 12 \\
\hline
\end{tabular}

Many rules and policies were issued meant to regulate a sustainable behaviour of tourists and many authors (Jacobson \& Robles, 1992; Juvan \& Dolnicar, 2016; Wang et al., 2018) have promoted sustainable ways of taking holidays through the limitation of natural resources (Gossling, 2002), decreasing consumption at the destination (Tsun Hung et al., 2013) and buying environmentally labelled products (Esparson et al., 2013). Weiler and Black (2014) claim that tour guiding approach towards sustainability envisages more dimensions such as enhancing understanding and valuing, influencing and monitoring behaviour, fostering post-visit attitudes and behaviours. 
Tourists can choose to spend their holidays sustainably by recycling, reducing waste and undertaking environmentally friendly activities while hollidaying such as walking on pre-designated trails, avoid using off road vehicles to reduce greenhouse gas emissions and spend vacations closer to their home (Juvan and Dolnicar, 2016). The hosts of tourist destinations worldwide have gradually become aware of the importance to protect environmental quality both for their own helath and to maintain destination competitiveness to attract more tourists (Wang et al., 2018). Hosts play key roles into educating tourist' behaviour in tourist destinations. Therefore we can state that a virtours circle of sustainability in tour guiding involves the tour guides and hosts as key elements in shaping tourists' behaviour (Figure 1).

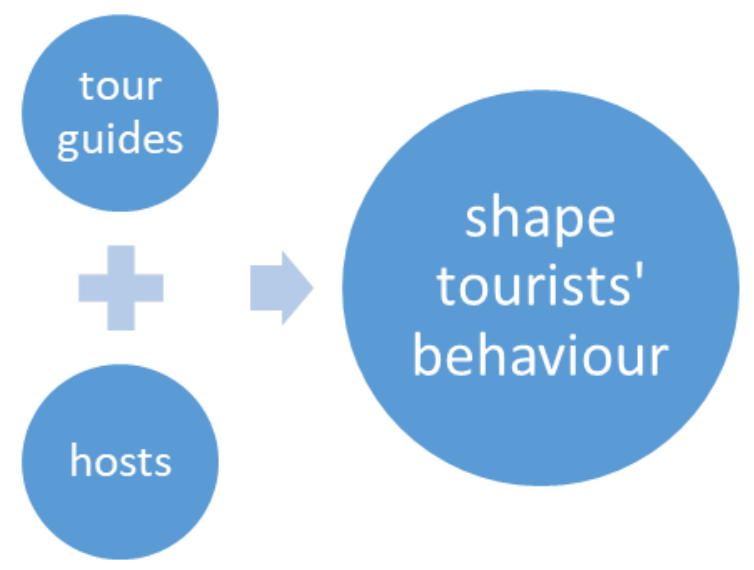

Figure 1. Sustainable approach with key actors for shaping tourists' behaviour at destinations

\section{CONCLUSIONS}

Highlighting the tourist guides' role in developing and sustaining the local economy is a sine-qua-non condition that is increasingly necessary both locally and nationally. This is due to the dynamic and complex nature of tourism over the last period, amid mutations in human society, marked by progress in other economic branches and beyond.

The results' analysis obtained from the consultations with the tourist guides showed their important role in facilitating contacts between tourists and local communities, as well as encouraging tourists to buy the specific products of the place. In this way, tourism as an economic activity proves to be an essential supporter for local economies, while the tourist guide is the mediator between local communities and tourists. The role of the tourist guide in promoting the sustainable development of tourist destinations emerges from their desire that tourism resources be accessible for the next generations (58 people expressing their wish) alongside the idea of preserving and protecting vulnerable resources, by choosing alternative attractions where necessary (47 respondents). Thus the same preserving and protecting trend of tourist resources and the environment have been found by guides among tourists with whom they were involved over time. In conclusion, the role and importance of tourist guides in the development and support of local economies, in line with the principle of sustainable development detaches from their actions meant to facilitate direct contact with the local population, encouraging tourists to acquire local products and promote host-guest interactions. The consumed tourist resources should be transmitted as unaltered as possible to the next generations, by their conservation, protection and sustainable valorization during the guided tour process. 


\section{REFERENCES}

Bar, R., Tătar, C., F., Herman, G., V., (2016), Satisfaction degree rating of tourist services in Buziaş spa, Timiş̧ County, Romania, GeoJournal of Tourism \& Geosites, 18(2).

Bryman, A., (2012), Social Research Methods, 4th edition, Oxford University Press, USA.

Chelcea, S., (2007), Metodologia cercetării sociologice. Metode cantitative și calitative, Ed. Economică, București.

Christie, M., F., Mason, P., A., (2010). Transformative Tour Guiding: Training Tour Guides to be Critically Reflective Practitioners. Journal of Ecotourism, 2:1, 1-16, DOI: 10.1080/14724040308668130.

Collins, V., R., (2000), Becoming a tour guide: Principles of guiding and site interpretation, Cengage Learning EMEA.

Comanescu L., (2012), Ghid de turism, Eurocor - Module 1, p. 4, ISBN 973-85938-1-6.

De Beer, A., Rogerson C., M., Rogerson J., M., (2014), Decent Works in the South African Tourism Industry:Evidence from Tourist Guides, Urban Forum, 25: 89-103, DOI 10.1007/s12132-013-9199-8.

Esparon, M., Gyuris, E., Stoeckl, N., (2013), Does ECO certification deliver benefits? An empirical investigation of visitors' perceptions of the importance of ECO certification's attributes and of operators' performance. J. Sustainable Tourism, 22 (1),148e169.

Gozner, Maria, (2015), Solutions for the development of leisure tourism by specific arrangements (cyclotourism) in the Albac - Arieşeni territorial system (Alba County, Romania), GeoJournal of Tourism and Geosites, VIII, no. 1 (15), p. 59 - 66.

Guirk, P., M., Mc, O'Neill, P., (2015), Using questionnaires in qualitative human geography, in: I. Hay (Ed.), Qualitative Research Methods in Human Geography, Oxford University Press, South Melbourne, 2005, pp. 147-162.

Hu, W., Wall, G., (2012), Interpretative Guiding and Sustainable Development: A Framework, Tourism Management Perspective, 4, Elsevier.

Ilieş, Al., Ilieş, Dorina, Tătar, Corina, Josan, Ioana, Blaga, L., (2008), Identity and Local Tourist Sustainabilityin the Arieseni Resort, Alba County, Romania, Conditions of the Foreign Tourism Development. Central and Eastern Europe, vol. 10, Tourism in Geographical Environment, published by the University of Wroclaw, Department of Regional and Tourism Geography.

Juvan, E., Dolnicar, S., (2016), Divers of pro-environmental tourist behavior are not universal. Journal of Cleaner Production, 166, pp 879-890.

Herman, G., V., Grama, V., Buhaș, R., Ilieș, D., C., Stance, L., (2016), Research on the professional trajectory of the highschool and university students from the fields of geography and physical education, Annals of the University of Oradea, Geography Series/Analele Universitatii din Oradea, Seria Geografie, 26(1).

Jacobson, S., K., Robles, R., (1992), Ecotourism, Sustainable Development, and Conservation Education: Development of a Tour Guide Training Program in Tortuguero, Costa Rica, Environmental Management Vol. 16, No. 6, pp. 701-713, Springer.

Lovrentjev, S., (2015), Education of Tourist Guides: Case of Croatia, Procedia Economics and Finance 23, 555 - 562, Elsevier.

McGuirk, P., M., O'Neill, P., (2005), Using Questionnaires in Qualitative Human Geography, in: I. Hay (Ed.), Qualitative Research Methods in Human Geography, Oxford University Press, South Melbourne, 2005, pp. 147-162.

Pond, K., L., (1993), The Professional Guide, New York: Van Nostrand Reinhold.

Randall, C., Rollins, R., B., (2009), Visitor perceptions of the roles of tour guides in natural areas, Journal of Sustainable Tourism, vol.17, no.3, pp 357-374.

Shaw, G., Williams, M., A., (2004), Tourism and Tourism Spaces, SAGE Publications, London.areas, Journal of Sustainable Tourism, volume 17, issue 3, Routledge.

Tătar, C., F., Herman, G., V., (2013), Identity Encounters, Host-Guest Interractions in the Land of Moţi, GeoJournal of Tourism and Geosites 11(1): 66-74.

Tatar, C., Herman, G., Giurgiu, A., (2017), Analysis of the Licensed Tour Guides' Evolution of Romania and Critical Issues Affecting their Activity, Analele Universitatii din Oradea, Seria Geografie, year XXVII, no. 2, pp 230-235.

Tsung, Hung, L., Fen-Hauh, J., Chung-Cheng, Y., (2013), Conceptualizing and measuring environmentally responsible behaviors from the perspective of community based tourists, Tourism Management 36, 454e486.

Ungureanu, M., (2013), Touristic development of the andesite and kaolin quarries in Pleşcuţa commune, Arad county, Central European Regional Policyand Human Geography, Year III, no. 1, pp. 107-116.

Weiler, B., Black, R., (2014), Tour guiding research: Insights, issues and implications, (Vol. 62), Channel View Pub.

Wang, W., Wu J., Wu, M., Y., Pearce P., L., (2018), Shaping tourists' green behavior: The hosts efforts at rural Chinese, B\&Bs, Journal of Destination Marketing and Management, https://doi.org/10.1016/j.jdmm.2018.01.006, Elsevier.

Weiler B., Kim A., K., (2011), Tour guides as agents of sustainability: Rhetoric, reality and implications for research, Tourism Recreation Research, 36(2), 113-125.

**** (2017), Minsistry of Tourism of Romania, http://turism.gov.ro/wpcontent/uploads/2016/o8/GhiziAtestati15122016.xls.

*** (2004), The Order of the Ministry of Transports, Constructions and Tourism no. 637/2004 for the approval of the methodological norms regarding the conditions and criteria for the selection, schooling, certification and use of tourist guides, with subsequent modifications and completions.

Submitted:

17.07.2017
Revised:

12.04.2018
Accepted and published online 16.04.2018 